\title{
Physico-chemical and Functional Characteristics of Fermented Cassava Flour by Lactobacillus casei using Submerged and Solid-State Fermentation
}

\author{
Nurhayati \\ Dept. of Agricultural Products \\ Technology \\ University of Jember \\ Jember, Indonesia \\ nurhayati.ftp@unej.ac.id
}

\author{
Jayus \\ Dept. of Agricultural Products \\ Technology \\ University of Jember \\ Jember, Indonesia \\ jayus.ftp@unej.ac.id
}

\author{
Hidayatul Fijriyah \\ Dept. of Agricultural Products \\ Technology \\ University of Jember \\ Jember, Indonesia \\ nhyati04@yahoo.com
}

\begin{abstract}
Abstract Utilization of cassava flour in the food industry had weakness, which were less stability and low the paste resistance because it couldn't resist to heat and acid conditions. Fermentation was an alternative that can be done to improve the properties of starch polymers, such as viscosity, gelatinization, and rheology. The research were to characterize the physico-chemical and functional properties of fermented cassava flour by Lactobacillus casei using submerged and solidstate fermentation. The results showed that the whiteness degree of cassava flour fermented by Lactobacillus casei ranged from 98-100, higher than cassava flour without fermentation 97. Amylose content of cassava flour fermented using BAL in submerged culture (13.7\%) higher than spontaneous fermentation in submerged culture $(\mathbf{1 1 . 0 3 \%})$. Cassava flour fermented in submerged had WHC $(326,7 \%)$ and OHC $(710,3 \%)$ value higher than cassava flour in solid-state fermentation. Gelatinization temperature of fermented cassava flour was lower $\left(69.7^{\circ} \mathrm{C}\right)$ than cassava flour non-fermentation $\left(70.4^{\circ} \mathrm{C}\right)$. The viscosity of cassava flour fermented using BAL $(5135 \mathrm{cP})$ had a peak value higher than the fermented cassava flour $(4495 \mathrm{cP})$, with longer time $(4.33 \mathrm{~min})$ and lower temperature $\left(72.55^{\circ} \mathrm{C}\right)$. It can be concluded the fermented cassava flour using submerged culture is better than solid culture.
\end{abstract}

Keywords-Cassava flour, Fermentation, Lactobacillus casei, Functional properties

\section{INTRODUCTION}

Using of cassava flour is very broad both as food and nonfood ingredients. For example, the use of cassava flour in the food industry is for thickener, and as a food stabilizing agent, while in the non-food industry such as paper, pharmaceuticals, and biofuel production. The resulting quality differences can be influenced by the nature or characteristics of cassava flour used. The use of cassava flour as the main ingredient in the industry has weaknesses and constraints, because of its limited nature and characteristics[1]. The limitations of the function of cassava flour are due to the stability, low paste resistance due to starch properties that are not resistant to heat and acidic conditions[2]. Modification of cassava flour is an alternative that can be done to improve the properties of starch polymers, such as paste viscosity, rheology that can improve the quality of snack products[3]

According to Reddy [4], starch functionality in food or non-food products depends on the physical properties of starch. The physical properties of starch are influenced by two main components in starch namely amylose and amylopectin. According to Matz [5], the level of development and texture of snacks is influenced by the ratio of amylose and amylopectin. According to Balagopalan et al. [6], the texture of starch-based products was obtained from changes in starch during and after cooking. Some factors that influence the product texture include gelatinization, expansion, viscosity, and retrogradation. $\mathrm{pH}$ factors on starch can also affect the quality of starch-based products. Reddy [4], reported that lactic acid bacteria have amylolytic properties which are capable of producing amylase enzymes to degrade starch. Lactic acid bacteria will destroy the cellulose that wraps starch, so that a fine-textured flour is obtained. According to Rahman [7], probiotic microbes that produce lactic acid fromspecies Lactobacillus produce cellulase enzymes.

Based on the above description, it can be done fermentation on cassava chips as a solution to increase the speed of gelatinization, increase the development power, viscosity, and retrogradation of the flour produced. Fermentation is carried out in submerged culture and / or solid culture, which is expected to improve the physicochemical and functional properties of cassava flour. Therefore, it is necessary to examine the physicochemical and functional characteristics of fermented cassava flour using commercial products of rich fermented milk Lactobacillus casei as starter. The purpose of this study was to determine the physicochemical and functional characteristics of cassava flour from fermented and dense culture using Lactobacillus casei.

\section{METHODS}

\section{A. Materials}

The main ingredients used in this study are cassava and "Yakult" beverage products as starter. Cassava was obtained from cassava sellers in Tanjung Market-Jember Regency East Java Indonesia, with the type of white cassava.

\section{B. Methods}

The research was carried out in five stages: the first stage was pre-process, the second stage was preparation of starter immersed culture carried out dilution of commercial products rich in fermented milk contain L. casei, as much as $65 \mathrm{ml}$ diluted in $1500 \mathrm{ml}$ of water was assumed to be $4.3 \times 10^{6} \mathrm{cfu} /$ $\mathrm{ml}$ of bacteria for culture of solid commercial products rich $L$. casei-fermented milk $65 \mathrm{ml}$ was taken $15\left(1.5 \times 10^{9} \mathrm{cfu} / \mathrm{ml}\right.$ 
bacteria), the third stage was the fermentation stage which was carried out in a plastic bag and placed in a room with a temperature of $28^{\circ} \mathrm{C}$. Fourth, the siege and sifting, the fifth stage is the testing of the physicochemical and functional properties of flour fermented.

a. Fermentation stage. Solid fermentation was carried out without the addition of water, as much as $250 \mathrm{~g}$ of cassava chips added with commercial fermented milk rich in $L$. casei as much as $15 \mathrm{ml}$. The fermentation of submerged culture was done by adding water with a ratio of 1: 1, as much as $250 \mathrm{~g}$ of cassava chips were added with a starter which had been diluted by $250 \mathrm{ml}(1.72 \mathrm{x}$ $\left.10^{4} \mathrm{cfu} / \mathrm{ml}\right)$. Fermentation is carried out vulnerable at 24, 48 and 72 hours. After reaching the time of fermentation the material is taken and dried using sunlight.

b. The fifth stage, carried out white degree analysis [8], moisture content [9], swelling power [10], measurement of thermal properties of flour using Differential Scanning Calorimetry (DSC) [11], acidity ( $\mathrm{pH})$ of water soak, amylose content [12], starch amylography profile using Rapid Visco Analyzer [13], WHC and OHC [14].

\section{Analysis of $\mathrm{pH}$ value}

$\mathrm{pH}$ measurements are carried out using a $\mathrm{pH}$ meter. The sample in the form of liquid is taken about $50 \mathrm{ml}$ then stirred until homogeneous then the $\mathrm{pH}$ is measured. The $\mathrm{pH}$ meter is standardized with a buffer solution at $\mathrm{pH} 4, \mathrm{pH} 7$ and $\mathrm{pH} 9$. Electrodes are rinsed and dried with a tissue then dipped in a sample.

\section{Analysis of whiteness degree}

This analysis is carried out using a color reader. Before use, the color reader is calibrated with the GOLD trademark F4 paper standard. A number of ingredients are placed in a cup, then target the sample at five points to find out the values of $\mathrm{L}$, $\mathrm{a}$ and $\mathrm{b}$ standard. The white degree is obtained based on the formula:

$$
\mathrm{w}=100-\left\{(100-\mathrm{L})^{2}+\left(\mathrm{a}^{2}+\mathrm{b}^{2}\right)\right\}^{0.5}
$$

\section{E. Analysis of water content}

Content is carried out in accordance with the AOAC method. The water content analysis procedure begins with drying the weighing bottle for 15 minutes at a temperature of $100-105^{\circ} \mathrm{C}$, then cooled in a desiccator for 15 minutes and weighed (a). The sample is weighed as much as 1 gram in a weighing bottle (b) then oven for 24 hours at a temperature of $100-105^{\circ} \mathrm{C}$, then cooled in a desiccator for 15 minutes and weighed (c). Moisture content is calculated by the formula:

$$
\% \text { water content }=(b-c) /(b a) \times 100 \%
$$

\section{Description:}

$\mathrm{a}=$ the weight of the bottle weighs empty $(\mathrm{g})$

$\mathrm{b}=$ weight of the weighing bottle and sample $(\mathrm{g})$

$\mathrm{c}=$ weight of the weighing bottle and sample after oven $(\mathrm{g})$

\section{F. Analysis of amylose content}

Amylose content is carried out according to the method of Apriyantono[12]. Sample amylose content is calculated based on the equation of the curve obtained by the following formula:

$$
\text { Amylose }(\%)=(\mathrm{A} \times \mathrm{DF} \times \mathrm{V}) /(\mathrm{S} \times \mathrm{W}) \times 100 \%
$$

Description:

A: Absorbance of the sample

S: Slope / slope of the curve

DF: Dilution factor

$\mathrm{V}$ : final sample volume (ml)

$\mathrm{W}$ : sample weight (mg)

\section{G. Analysis of thermal properties}

Measurement of the thermal properties of cassava flour using Differential Scanning Calorimetry (DSC) tools [11]. The tool is calibrated using indium (melting point $156.78^{\circ} \mathrm{C}$ ), $2 \mathrm{mg}$ of sample is inserted into aluminum pan and hermetically closed. Measurements were carried out at a temperature range of $30-140{ }^{\circ} \mathrm{C}$ with a heating rate: $10^{\circ} \mathrm{C} /$ minute to get the graph, then analyzed the crystalline temperature, glass transition, and enthalpy.

\section{H. Analysis of amylographic profile}

The modified gelatinization profile of cassava flour was analyzed using Rapid Visco Analyzer (RVA) [13]. A total of $3 \mathrm{~g}$ of sample (dry weight) was weighed in a container of RVA, then added $25 \mathrm{ml}$ of aquadest. Measurements with RVA include the heating and cooling phase of the sample container with a rotational speed of $160 \mathrm{rpm}$. From this the peak viscosity is obtained, the temperature of the paste (the initial temperature of the increase in viscosity), the temperature of the peak viscosity, the heat viscosity (viscosity after heating $95^{\circ} \mathrm{C}$ for 5 minutes), the final viscosity (viscosity after cooling at $50^{\circ} \mathrm{C}$ for 2 minutes), viscosity breakdown relative (the ratio between the difference in peak viscosity, expressed in percent) and the relative reverse viscosity (the ratio between the difference in final viscosity and heat viscosity to the heat viscosity).

\section{Analysis of swelling power}

This analysis is carried out according to the method used by Darmawan [10]. A sample of 0.1 grams was put in $10 \mathrm{ml}$ of distilled water. Mocaf solution was heated at $60^{\circ} \mathrm{C}$ for 30 minutes, then the resulting paste was centrifuged $2500 \mathrm{rpm}$ for 15 minutes. Growth power can be calculated by the formula:

Growth power $=($ paste weight $) /($ sample dry weight $) \times 100 \%$

\section{J. Analysis of water holding capacity and oil holding capacity}

Sample $0.1 \mathrm{~g}$ was suspended in $7 \mathrm{ml}$ of water and shaken for 1 minute, then centrifuged at $3000 \mathrm{rpm}$ for 10 minutes. The resulting supernatant is slowly discarded, the resulting sediment is weighed.

A sample of $0.1 \mathrm{~g}$ was mixed with $7 \mathrm{ml}$ of vegetable oil and shaken for 1 minute. The starch suspense was centrifuged at $3000 \mathrm{rpm}$ for 10 minutes, the resulting supernatant was slowly discharged, the resulting precipitate was then weighed [14] .

WHC/OHC $=(($ weight of the end-weight of the bottle $)$-weight of the sample $) /($ sample weight $) \times 100 \%$ 


\section{K. Data analysis}

Data from observations using DSC and RVA tools were analyzed descriptively, while other research data were tested for diversity using ANOVA tables $(\alpha=5 \%)$. Significantly different results continued using the least significant difference (LSD).

\section{RESULTS AND DISCUSSION}

\section{A. $p H$ value of modified cassava flour}

$\mathrm{pH}$ value is closely related to consumer acceptance of fermented cassava flour products. Controlled fermentation has decreased from 0 hours to 72 hours, from 6.95 to CK24 6.05; CK48 5,85; CK72 5.70 (Figure 1). This is thought to be due to the longer fermentation resulting in the accumulation of organic acids produced by metabolism during fermentation. The decrease in $\mathrm{pH}$ in $\mathrm{CK}$ is more stable than $\mathrm{CS}$ although there is no drastic decline, this is due to the help of lactic acid bacteria in CK. According to Prastyaharasti [15], the decrease in $\mathrm{pH}$ value during fermentation is one proof of the accumulation of lactic acid as the main product of heterofermentative bacterial activity. The $\mathrm{pH}$ value which decreases due to longer fermentation. The longer the fermentation, the more amount of acid produced. Fermentation will produce volatile acids including lactic acid, acetic acid, formic acid, butyric acid and propionic acid.

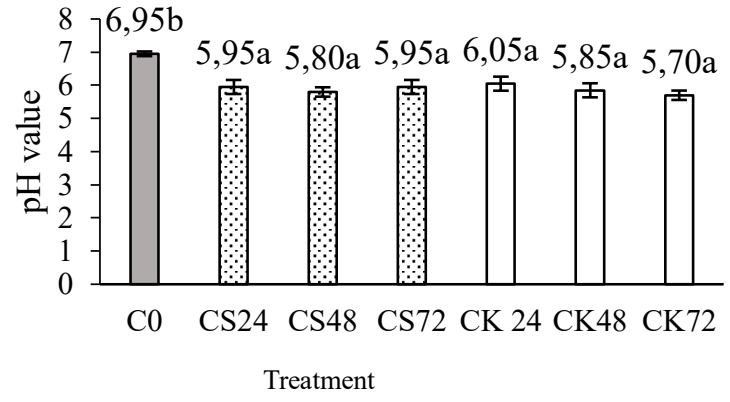

Figure 1. $\mathrm{pH}$ value of native cassava flour $(\mathrm{K})$, spontaneous fermented cassava flour (CS), controlled fermented cassava flour (CK), spontaneous solid-state fermented cassava flour

(PS), controlled solid state fermented cassava flour (PK)

\section{B. Whiteness Degree of modified cassava flour}

The results of brightness measurements of fermented cassava flour in this study ranged from 97.13 to 100.77 (Figure 2). CK72 has the highest brightness value of 100.77 . This is possible to influence the cellulase enzyme produced by BAL during fermentation. Cellulase enzymes play a role in degrading cellulose which encapsulates starch in cassava so that starch is more easily released. Soaking chips using water or submerged culture fermentation can increase the whiteness degree of cassava flour. This is because the browning reaction during the stripping process can be stopped after the material comes into contact with water during soaking.

The presence of $L$. casei which produces cellulase enzymes can cause color changes in PK72 to become darker. According to Ikram [16], hydrolysis of the cellulase enzyme in the $\beta$-glucosidase that breaks down cellobiose can produce glucose. The more glucose produced will cause the browning reaction to occur during drying of the material causing darker color.

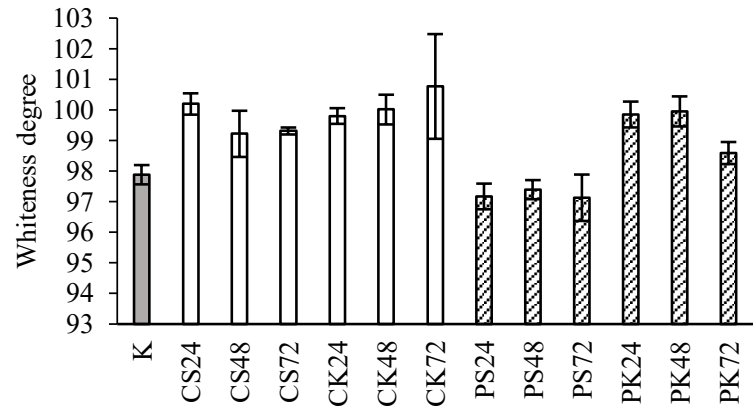

Treatment

Figure 2. Whiteness degree of native cassava flour (K), spontaneous fermented cassava flour (CS), controlled fermented cassava flour (CK), spontaneous solid-state fermented cassava flour (PS), controlled solid state fermented cassava flour (PK)

\section{Water Content of modified cassava flour}

Content CS-CK and PS-PK moisture content has a water content value between $10.69 \%$ to $11.87 \%$ lower than unfermented flour which is $12.61 \%$ (Figure 3). This is due to the ability of the material to hold water lower so that water is easily evaporated during drying. The longer the fermentation, the lower the binding capacity of the water. According to Winata [17], granules that have swelled tend to have larger inter-cell cavities, so that during drying the water contained will be more easily released.

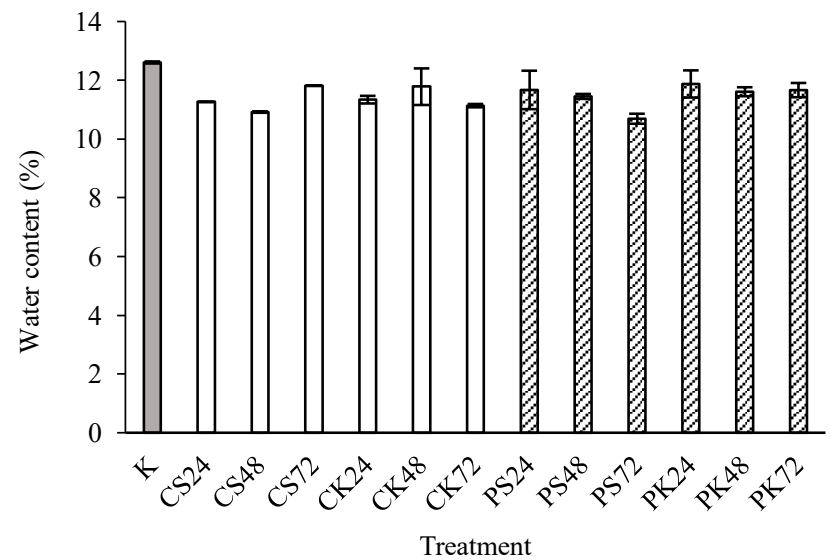

Figure 3. Water content of native cassava flour (K), spontaneous fermented cassava flour (CS), controlled fermented cassava flour (CK), spontaneous solid-state fermented cassava flour (PS), controlled solid state fermented cassava flour (PK)

The combination treatment of CS72 and CK48 experienced an increase in water content, namely $11.81 \%$ and $11.78 \%$ of CS48 $10.92 \%$ and CK24 11.34\%. An increase in water content is estimated due to more starch content. More materials containing starch have greater water retention ability. 


\section{Amylose content of modified cassava flour}

Amylose content of cassava flour ranged from 11.03 to $13.70 \%$ (Figure 4). Increased amylose levels occur in PK48 $(13.05 \%)$. This increase is thought to be due to the branching structure of amylopectin (debranching) resulting in oligomers with shorter polymer degrees such as amylose during the heating process. Amylose levels increase due to degradation by lactic acid. Degradation occurs inregions amorphous because acid diffuses into starch granules and attacks oxygen at the glycosidic bonds found in $\alpha-1,4$ and $\alpha-1,6$ so as to produce carbocationic intermediates that are unstable and can react with water in starch granules [18].

Amylose content of cassava flour fermented by CK72, and PK72 decreased. It is possible to use amylose as a carbon source for microbial activity. Microbes convert amylose to sugar in an effort to obtain energy for its growth and activity [19]. The longer the fermentation, the more amylose is converted into simple sugars so that the amylose content in the material will decrease. During fermentation, the cassava starch granules used will undergo hydrolysis by microbes that produce monosaccharides which are then used by microbes to produce organic acids. Subagio [14] reported that there was amylase enzyme activity during the fermentation process. This shows that microbes that grow in cassava can produce amylase enzymes that can degrade amylose in cassava, so that the amylose content is lower than unfermented flour.

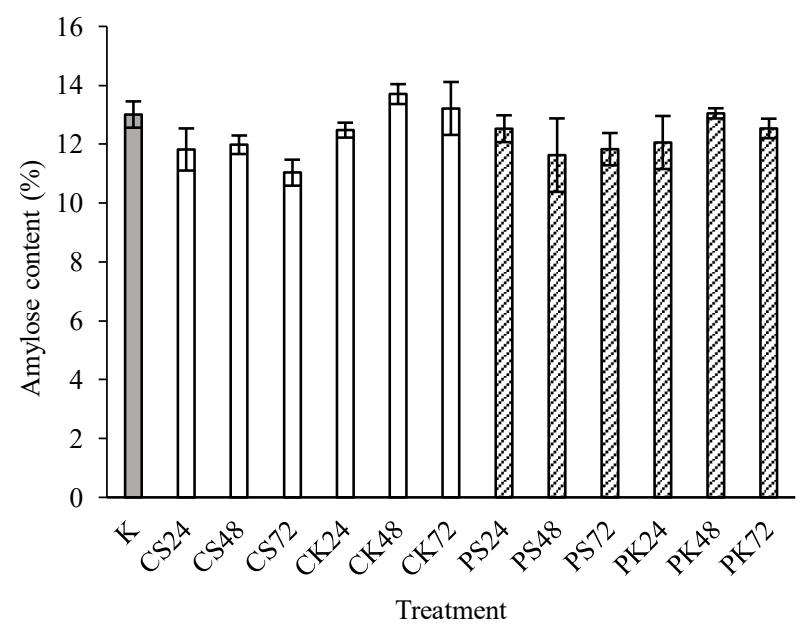

Figure 4. Amylose content of native cassava flour (K), spontaneous fermented cassava flour (CS), controlled fermented cassava flour (CK), spontaneous solid-state fermented cassava flour (PS), controlled solid state fermented cassava flour $(\mathrm{PK})$

\section{E. Swelling power of modified cassava flour}

Swelling power CS72 cassava flour increased with the value of $7.39 \%$, this is because of a low amylose bond is CS72 $11.03 \%$ (Figure 5). According to Lindriati [18], a high proportion of the amylopectin branch chain contributes to an increase in swelling value. Therefore, the higher the amylopectin level, the higher the developing power. The more starch granules that swell, the greater the viscosity value [14], which causes an increase in flowering power. The same thing also happened in CK72, PK24, and PK48, where the growth power value increased with amylose levels decreasing and developing power decreased with amylose levels increasing.

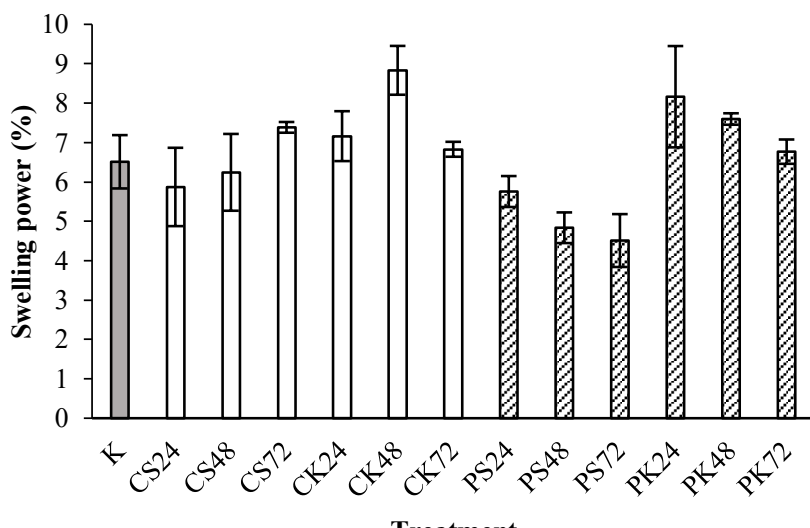

Figure 5. Swelling power of native cassava flour (K), spontaneous fermented cassava flour (CS), controlled fermented cassava flour (CK), spontaneous solid state fermented cassava flour (PS), controlled solid state fermented cassava flour (PK)

The growth power of CK48 cassava flour (8.83\%) increased along with the increase in amylose content $(13.70 \%)$. This increase occurs because amylose can form complexes with lipids in starch. According to Charles et al [20], the low lipids in starch cause the complex between amylose and lipids to be less influential in inhibiting swelling.

\section{F. Thermal properties of modified cassava flour}

The observed thermal properties showed a decrease in temperature at $\mathrm{T}_{0}$, Tp and Tc compared to cassava flour control (Table 1). The decrease in gelatinization temperature and enthalpy in CK72 compared to K, is possible because of a decrease in hydrogen bonds which can reduce the amount of energy needed to decompose and melt during gelatinization. Hydrogen bonds in starch granules function to maintain granular structure. According to Pratiwi [21], the occurrence of cutting $\alpha-1.6 \mathrm{D}$-glycosidic bonds can increase the peak of the gelatinization temperature $(\mathrm{Tp})$ and the temperature conclusion ( $\mathrm{Tc}$ ) and decrease the $\Delta \mathrm{H}$. However, from the results of reading the data there was a decrease in the gelatinization temperature in the fermented sample. It is possible that fermentation using $L$. casei cannot cut the $\alpha-1,6$ D-glycosidic bond.

The value of $\Delta \mathrm{H}$ cassava flour without fermentation $(\mathrm{K})$ is $5,358 \mathrm{~J} / \mathrm{g}$ which is lower than $\Delta \mathrm{H}$ fermented cassava flour BAL culture solid (PK72) which is 6,205 J / g, while fermented cassava flour BAL immersed culture (CK72) has $\Delta \mathrm{H}$ the lowest is $5.125 \mathrm{~J} / \mathrm{g}$. The decrease in $\Delta \mathrm{H}$ occurs due to a decrease in arrangement and a reduction in the stability of the structure double helix in hydrogen bonds due to the gelatinization process. The higher the gelatinization temperature, the stronger the crystalline structure or the higher molecular regularity [19] v. According to Chung [23], enthalpy $(\Delta \mathrm{H})$ correlates withquantities double helix and crystalline. $\Delta \mathrm{H}$ shows the loss of thebond arrangement double helix which is one of the parameters that is strongly influenced by amylose content, chain length of amylopectin and amylose- 
lipid complex. This shows that $\mathrm{K}$ flour has a strong crystalline structure and high form regularity.

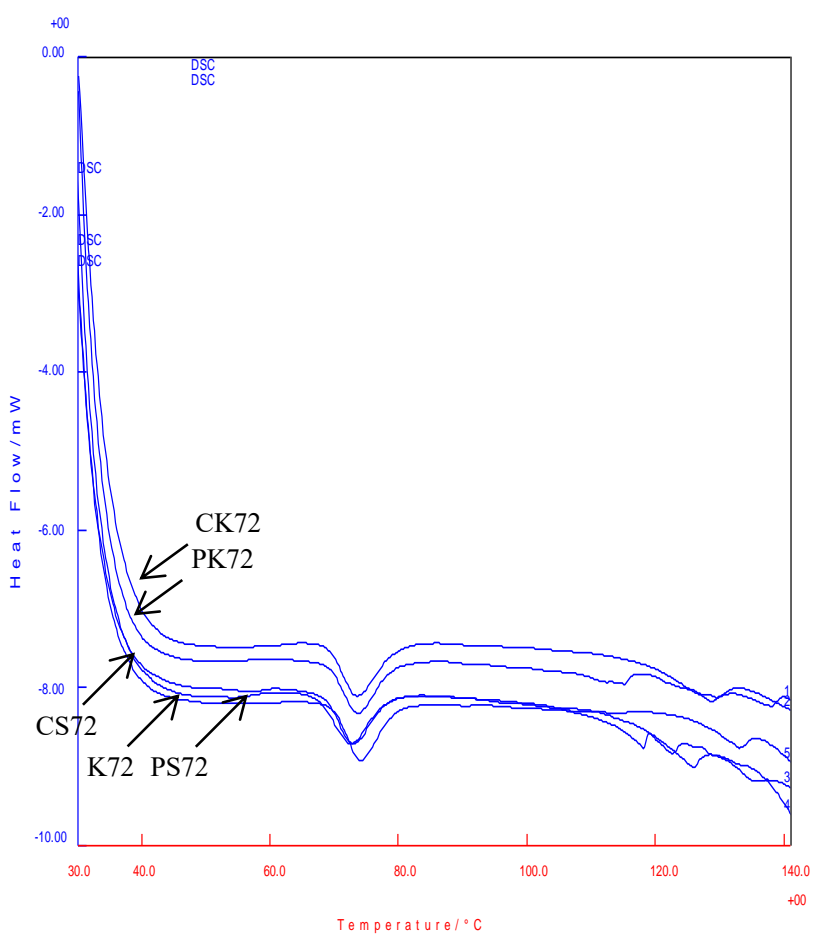

Figure 6. Thermal properties of native cassava flour $(\mathrm{K})$, spontaneous fermented cassava flour (CS), controlled fermented cassava flour (CK), spontaneous solid-state fermented cassava flour (PS), controlled solid state fermented cassava flour (PK)

Unfermented cassava flour $(\mathrm{K})$ has a glass transition temperature range $(\Delta \mathrm{T}) 7.1^{\circ} \mathrm{C}$, narrower than fermented cassava flour which indicates crystalline homogeneity. According to Widyatmoko et al. [22], the widening of the temperature range occurs in starch with high amylose, the temperature will increase with the increase in amylose content and water content which indicates the heterogeneity of amylopectin short chain re-formation and the formation of amylose-lipid complexes. This proves that fermented cassava flour which has a high $\Delta \mathrm{T}$ value re-forms the $\alpha-1.6 \mathrm{D}$ glycosidic bond.

\section{G. Amylographic profile of modified cassava flour}

Observation of amylographic profile was carried out on pasting temperature, peak, trough, stability of paste (breakdown), setback and peak time (Table 2). Gelatinization temperature is the temperature when it starts detecting increased viscosity in the system. The highest gelatinization temperature is PK72 of $74.40{ }^{\circ} \mathrm{C}$, then followed by $\mathrm{K}, \mathrm{CS} 72$, CK72, and PS72 with a value of $4.20^{\circ} \mathrm{C}$, respectively; 73,50 ${ }^{\circ} \mathrm{C} ; 72,55^{\circ} \mathrm{C}$ and $72,55^{\circ} \mathrm{C}$. Gelatinization occurs due to water entering the amorphous area (amylose part). The water will increase the swelling of the granules until the granule diameter increases. Gelatinization takes place with warming that continues to increase, so that the granules break. This causes water and starch molecules (especially amylose) to come out and enter the solution system.
Table 1. Thermal properties of cassava starch by $L$. casei during $72 \mathrm{~h}$ fermentation

\begin{tabular}{|c|c|c|c|c|c|c|c|c|}
\hline \multirow[b]{2}{*}{$\begin{array}{l}\text { Treat } \\
\text { ment }\end{array}$} & \multicolumn{5}{|c|}{ Thermal stability } & \multirow[b]{2}{*}{$\begin{array}{c}\% \\
\text { decre } \\
\text { ase } \\
\text { of } \mathrm{T}_{0}\end{array}$} & \multirow[b]{2}{*}{$\begin{array}{c}\% \\
\text { decre } \\
\text { ase } \\
\text { of } \mathrm{Tp}\end{array}$} & \multirow[b]{2}{*}{$\begin{array}{c}\% \\
\text { decre } \\
\text { ase } \\
\text { of } \mathrm{Tc}\end{array}$} \\
\hline & $\begin{array}{l}\mathbf{T}_{0} \\
\left({ }^{\circ}\right. \\
\text { C) }\end{array}$ & $\begin{array}{l}\mathbf{T} \\
\mathbf{p} \\
\left(^{\circ}\right. \\
\mathbf{C}) \\
\end{array}$ & $\begin{array}{c}\text { Tc } \\
\left({ }^{\circ} \mathrm{C}\right. \\
)\end{array}$ & $\begin{array}{c}\Delta \mathbf{T}=\mathbf{T c} \\
-\mathbf{T}_{\mathbf{0}} \\
\left({ }^{\circ} \mathbf{C}\right)\end{array}$ & $\begin{array}{l}\Delta \mathbf{H} \\
(\mathbf{J} / \\
\mathbf{g})\end{array}$ & & & \\
\hline K & $\begin{array}{l}70 \\
.4\end{array}$ & $\begin{array}{c}73 \\
.8\end{array}$ & $\begin{array}{c}77 . \\
5\end{array}$ & 7.1 & $\begin{array}{l}5.3 \\
58\end{array}$ & - & - & - \\
\hline CS72 & $\begin{array}{c}68 \\
.3\end{array}$ & $\begin{array}{l}72 \\
.2\end{array}$ & $\begin{array}{c}75 . \\
7\end{array}$ & 7.4 & $\begin{array}{c}5.8 \\
01\end{array}$ & 2.98 & 2.17 & 2,32 \\
\hline CK72 & $\begin{array}{l}69 \\
.7\end{array}$ & $\begin{array}{l}73 \\
.3\end{array}$ & $\begin{array}{c}77 . \\
2\end{array}$ & 7.5 & $\begin{array}{c}- \\
5.1 \\
25\end{array}$ & 0.99 & 0.68 & 0,39 \\
\hline PS72 & $\begin{array}{c}69 \\
.0\end{array}$ & $\begin{array}{l}72 \\
.6\end{array}$ & $\begin{array}{c}76 . \\
5\end{array}$ & 7.5 & $\begin{array}{l}5.6 \\
54\end{array}$ & 1.99 & 1.63 & 1,29 \\
\hline PK72 & $\begin{array}{l}69 \\
.7\end{array}$ & $\begin{array}{c}73 . \\
4\end{array}$ & $\begin{array}{c}77 . \\
0\end{array}$ & 7.3 & $\begin{array}{l}6.2 \\
05 \\
\end{array}$ & 0.99 & 0.54 & 0,65 \\
\hline
\end{tabular}

$\mathrm{To}=$ onset temperature $\left({ }^{\circ} \mathrm{C}\right), \mathrm{Tp}=$ peak temperature, $\mathrm{Tc}=$ conclusion temperature; $\Delta \mathrm{H}=$ entalphy

Table 2. Amylograph properties of cassava starch by L. casei during $72 \mathrm{~h}$ fermentation

\begin{tabular}{|c|c|c|c|c|c|c|c|}
\hline \multirow[b]{2}{*}{$\underset{\text { le }}{\text { Samp }}$} & \multirow[b]{2}{*}{$\begin{array}{c}\text { Peak } \\
1 \text { (cP) }\end{array}$} & \multirow[b]{2}{*}{$\begin{array}{l}\text { Trou } \\
\text { gh } 1 \\
\text { (cP) }\end{array}$} & \multirow[b]{2}{*}{$\begin{array}{c}\text { Brea } \\
\text { kdow } \\
\quad n \\
(\mathrm{cP})\end{array}$} & \multirow[b]{2}{*}{$\begin{array}{c}\text { Final } \\
\text { Visc } \\
\text { (cP) }\end{array}$} & \multicolumn{3}{|c|}{ Pea } \\
\hline & & & & & $\begin{array}{c}\text { Setba } \\
\text { ck } \\
(\mathrm{cP})\end{array}$ & $\begin{array}{c}k \\
T i m \\
e \\
(\mathbf{m i} \\
\text { n) }\end{array}$ & $\begin{array}{c}\text { Pasti } \\
\text { ng } \\
\text { Temp } \\
\left({ }^{\circ} \mathrm{C}\right)\end{array}$ \\
\hline $\mathrm{K}$ & 4495 & 2488 & 2007 & 3263 & 774 & 4.00 & 74,20 \\
\hline CS72 & 5045 & 2544 & 2501 & 3223 & 679 & 4.07 & 73,50 \\
\hline CK 72 & 5135 & 2642 & 2493 & 3400 & 758 & 4,33 & 72,55 \\
\hline PS72 & 4194 & 2335 & 1869 & 2967 & 642 & 3,93 & 72,55 \\
\hline PK72 & 4128 & 2132 & 1996 & 2808 & 676 & 4,33 & 74,40 \\
\hline
\end{tabular}

The peak viscosity (Peak 1) shows the initial condition of the gelatinized starch granule until it reaches maximum development then gradually breaks. The peak value of the viscosity (PV) of the CK72 sample, which is $5135 \mathrm{cP}$ is higher than the other samples. This is possible because of the high amylose content in CK72, which is $13.21 \%$. Granule swelling occurs due to the opening of the amylopectin structure during fermentation resulting in an increase in amylose content which plays a role in the binding of water.

Trough viscosity is the minimum value at constant temperature which measures the ability of the paste to withstand breakdown during cooling [23]. Cassava flour fermented by CK72 has the viscosity trough highest of 2642 $\mathrm{cP}$, while the viscosity of other cassava flour is lower. According to Matz [5], amylose provides a texture that is more resistant to breakability, so that during heating the CK72 granule (amylose content 13.21\%) is more resistant and constant.

The viscosity breakdown shows changes in granular structure due to heating. The highest peak viscosity of CK72 is $5135 \mathrm{cP}$ but also hasviscosity breakdown a highwhich is 2493 cP. According to Alvarado [24], a high decrease inviscosity breakdown results in more complete damage to the granule after the peak viscosity is achieved. The low viscosity breakdown shows the stability of the paste during heating. PS72 has a low breakdown viscosity which is $1869 \mathrm{cP}$, 
indicating the structure of starch granules is more stable during heating [22].

Viscosity Setback is a parameter to determine the retrogradation tendency and sineresis of the paste [22]. Viscosity is Setback obtained from the difference between the final viscosity and theviscosity trough. Unfermented cassava flour has theviscosity setback highest, which is $774 \mathrm{cP}$, compared to fermented cassava flour ranging from $642-758$ $\mathrm{cP}$. Agustin [23] reported that the higher the viscosity setback, the higher the tendency to form gel during cooling.

The final viscosity is a parameter that defines the quality of flour. Parameters that indicate the ability of flour to form thick paste after cooking and cooling and resistance to shear forces during stirring [22]. The highest final viscosity was found in BAL submerged culture fermented flour (CK72) which was $3400 \mathrm{cP}$, while the final viscosity of flour K, PK72, CS72, and PK72 were $3263 \mathrm{cP}, 2808 \mathrm{cP}, 3223 \mathrm{cP}$, and 2967 $\mathrm{cP}$, respectively.

Peak time is a parameter that measures the time of cooking pasta. Fermented cassava flour had a peak time of 4 minutes, fermented flour CK72, PK72, and CS72 had a higher peak time of 4.33 minutes, 4.33 minutes, and 4.07 minutes, respectively, but decreased at PS72 which was 3, 93 minutes.

\section{H. Water holding capacity of modified cassava flour}

Water holding capacity (WHC) is the ability of starch granules to absorb and hold water during mechanical treatment. The binding capacity of cassava flour water without fermentation (K) showed the lowest value of $210 \%$, while CS24 fermented flour showed the highest value of $326.7 \%$ (Figure 6). Other improvements also occurred in the combination of CK24 (312.3\%) and PK48 (310\%) treatments, this was due to the large number of hydroxyl groups. According to Lindriati [18], the hydroxyl groups in starch granules are able to bind water very strongly.

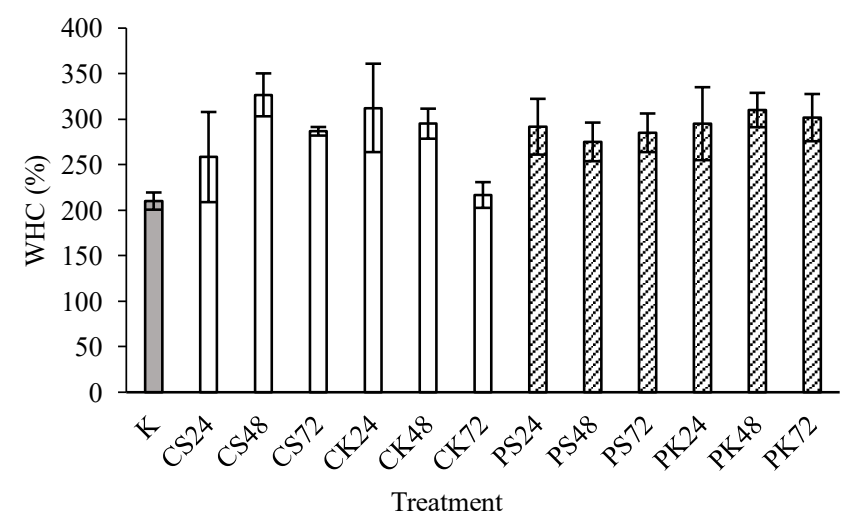

Figure 7. Water holding capasity of native cassava flour (K), spontaneous fermented cassava flour (CS), controlled fermented cassava flour (CK), spontaneous solid state fermented cassava flour (PS), controlled solid state fermented cassava flour (PK)

The combination of CS72 treatment decreased by $286.7 \%$. This is because during BAL fermentation produces amylase enzymes which hydrolyze amylose and short chain amylopectin. Lactic acid results from BAL can cause starch degradation during fermentation by oxidizing parts amorphous and then simultaneously hydrolyzing amylose and amylopectin [25]. Chung [26] explained the area degradation amorphous occurs because acid diffuses into starch granules and attacks oxygen at the glycosidic bonds found in $\alpha-1,4$ and $\alpha-1,6$ so as to produce carbocationic intermediates that are unstable and can react with water in granules starch.

\section{Oil holding capacity of modified cassava flour}

Oil holding capacity (OHC) is used to measure the ability of cassava flour without fermentation or fermentation in holding oil. The results of fermented cassava flour $\mathrm{OHC}$ measurements ranged from $513.3 \%$ to $710.3 \%$ (Figure 7 ). The increase in $\mathrm{OHC}$ values occurred in the combination of CS24 treatments to CS48, namely from $570 \%$ to $710.3 \%$. The increase in $\mathrm{OHC}$ value is thought to be the formation of amylose-lipid complexes on fermented cassava flour. Amylose-lipid complex is a form of interaction between lipids and starch. Amylose with a single helical structure with seven glucosyls for each cycle allows this interaction [27]. Oil absorption capacity in starch granules is possible because oil is trapped in a porous porous matrix which is capillary or in the helical structure of amylose or amylopectin due to the formation of amylose-lipid complexes. The binding ability of oil is influenced by lipophilic groups which envelop starch granules. Lipids which are in good starch contained in starch granules or which cover starch granules, cause starch granules to have a hydrophobic side so that they are thought to be able to bind to other components of oil or fat added from the outside[28].

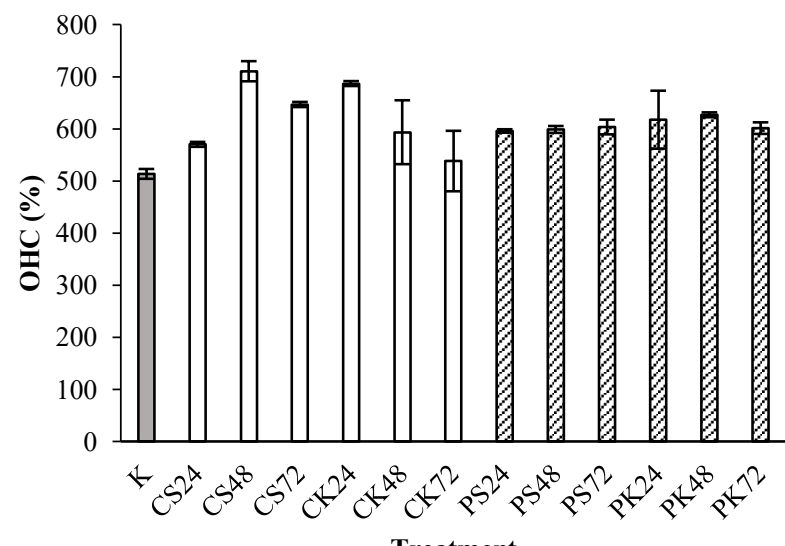

Figure 8. Oil holding capasity of native cassava flour (K), spontaneous fermented cassava flour (CS), controlled fermented cassava flour (CK), spontaneous solid state fermented cassava flour (PS), controlled solid state fermented cassava flour (PK)

\section{CONCLUSION}

Fermented cassava flour using $L$. casei in a submerged culture increased whiteness degree, amylose content, WHC, and $\mathrm{OHC}$. Gelatinization of fermented cassava flour takes place at a lower temperature. The viscosity peak of the fermented cassava flour is higher with a longer time (4.33 minutes) than unfermented cassava flour. It's can be concluded that the fermented cassava flour fermenting by $L$. casei is more stable from high temperature. 


\section{ACKNOWLEDGMENTS}

The authors are grateful to Center for Development of Advanced Science University of Jember for supporting this research.

\section{REFERENCES}

[1] Nurhayati N, Alfian AR. 2017. Quality Characteristics of Natura Edamame Jam Without Preservative Ingredient as Supplementary of Emergency Food. Advanced Science Letters. 23 (12): 2017

[2] Singh N, Chawla D, Singh J. 2004. Influence of acetic anhydride on physicochemical, morphological and thermal properties of corn and potato starch. Food Chemistry 86: 601-608. DOI: /10.1016/j.food chem.2003.10.008

[3] Syamsir E, Purwiyatno H, Dedi F, Nuri A Feri K. 2012. Effect of heatmoisture treatment (HTM) process on physicochemical characteristics of starch. Teknologi \&Industri Pangan. 23 (1) (Indonesian).

[4] Reddy G, Altaf M, Naveena BJ, Venkateshwar M, Kumar EV. 2008. Amylolytic bacterial lactic acid fermentation - A review. Biotechnology Advances. 26: 22-34. DOI: 10.1016 / j.biotechadv.2007.07. 004

[5] Matz SA. 1976. Snack food technology. AVI. Westport.

[6] Balagopalan C, Padmaja G, Nanda SK, Moorthy SN. 1988. Cassava in food, feed and industry. CRC Press, Florida.

[7] Rahman AM. 2007. Studying Chemical and Physical Characteristics of Tapioca Flour and Mocal (Modified Cassava Flour) as Peanut Coatings on Salted Peanut Products [Thesis]. Bogor: Bogor Agricultural University (Indonesian).

[8] Manual Book Color Reader. 2001. Color Reader CR-10 Operator Manual. Konica Minolta.

[9] AOAC [Association of Official Analytical Chemist]. 2005 Official Methods of Analysis of AOAC, International $18^{\text {th }}$ edition. Gaithersburg. USA.

[10] Darmawan MR, Andreas P, Jos B, Sumardiono S. 2013. Modification of cassava by fermentation process usingstarter Lactobacillus casei for food products. J. Chemical and Industrial Technology, 2 (4): 137-145.

[11] Chinsamran K, Kuakoon P, Vilai S, Klanarong S. 2005. Effect of lactic acid fermentation on physico-chemical properties of starch derived from cassava, sweet potato and rice. Kasetsart J. (Nat. Sci.) 39 (1).

[12] Apriyantono A, Fardias D, Puspitasari NL, Sedarnawati, Budjanto S. 1998. Instructions for food analysis laboratories. Bogor: PAU Food and Nutrition. IPB (Indonesian)

[13] USWA [United States Wheat Associates]. 2007. Rapid visco analyzer.wheat and flour testing method: a guide to understanding wheat and flour quality. Wheat Marketing Center, Inc., Portland, Oregon USA.

[14] Subagio A. 2003. Effect of addition of sword koro protein isolates (Canavalia ensiformis L) to the characteristics of the cake. Journal of Food Teknologi \&Industri Pangan, 14 (2): 136-143.

[15] Prastyaharasti L, Zubaidah E. 2014. Evaluation of the growth of Lactobacillus casei in medium skim milk substituted with red rice flour. Teknologi \& Industri Pangan. 2 (4): 285-296. (Indonesian )

[16] Ikram-ul-Haq S, Muhammad MJ, Zafar S, Tehmina S. 2015. Triggering of $\beta$-glucosidase production in trichoderma virida with nutritional and environmental control. J. of Applied Sciences Reasearch, 2 (11): 884889.

[17] Winata AY. 2001. Characteristics of sukun (Artocarpus altilis) parboilled flour produced by drume drying and their application as substitute flour on sweet bread [Thesisi]. Bogor Agricultural University (Indonesian).
[18] Lindriati T, Praptiningsih Y, Wijayanti DW. 2014. Physical characteristics of gel edible film made with variations in $\mathrm{pH}$ and ratio of casein and tapioca. Ilmu Dasar, Vol. 15 (1) (Indonesian).

[19] Anggraeni YP, Yuwono SS. 2014. The effect of natural fermentation on sweet potato chips (Ipomoea batatas) on the physical properties of fermented sweet potato flour. Teknologi \& Industri Pangan Vol. 2 (2): 59-69 (Indonesian)

[20] Charles AL, Chang YH, Ko WC, Sriroth K, Huang TC. 2005. Influence of amylopectin structure and amylose content on gelling properties of cultivars of cassava starches. J. Agric. Food Chemistry Vol 53 (7): 2717-2725. DOI: $10.1021 /$ jf048376 +

[21] Pratiwi M. 2016. Structural Changes of Arrowroot Starch (Marantha arudunacea L.) as the Impact of Multiple Treatments by Acyd Hydrolysis, Debranching, Autoclaving-cooling Cycles, and Hea Moisture Treatment (HMT) [Thesis]. Bogor: Bogor Agricultural University (Indonesian).

[22] Widyatmoko H, Subagio A, Nurhayati N. 2018. Physicochemical Properties of Cassava Starch Fermented by IndigenousTapai Yeasts. Agritech, 38 (2) 2018, 140-150 (Indonesian)

[23] Agustin S. 2011. Effects of non-starch polysaccharides on the gelatinization characteristics of breadfruit flour. Agroteknologi. ISSN 1858-2419 (Indonesian).

[24] Alvarado PM, Grosmaire L, Dufour D, Toro AG, Sanchez T, Calle F, Santander MAM, Ceballos H, Delarbre JL, Tran T. 2013. Combined effect of fermentation, sun-drying and genotype on breadmaking ability of sour cassava starch. Carbohydrate Polymers 98: 1137- 1146 DOI: $10.1016 /$ j.carbpol.2013.07.012.

[25] Nurhayati, Jenie BSL., Widowati S., Kusumaningrum, HD. 2014 Chemical Composition and Crystallinity of Modified Banana Flour by Spontaneous Fermentation and Autoclaving-Cooling Cycles Agritech. Vol. 34(2) //doi.org/10.22146/agritech.9504 (Indonesian).

[26] Chung HJ, Liu Q, Hoover R. 2009. The impact of annealing and heatmoisture treatment on rapidly digestible, slowly digestible and resistan levels in native and gelatinized corn, pea and lentil starches. Carbohydrate Polymers 75: 436-447. $\quad$ DOI: 10.1016 / j.carbpol.2008.08.006

[27] Faridah D.N, Fardiaz D, Andarwulan N, dan Sunarti, T.C. 2010 Structure Changes of Arrowroot (Maranta arundinaceae) Starch as Influenced by Acid Hydrolisis, Debranching and Autoclaving Cooling Modifications. Teknologi \&Industri Pangan, XXI (2) (Indonesian).

[28] Adebowale KO, Olu-Owolabi BI, Olawumi EK, Lawal OS. 2005. Functional properties of native, physically and chemically modified breadfruit (Artocarpus artillis) starch. Ind. Crops Prod., 21: 343-351. 